\title{
SOIL PHYSICAL ATTRIBUTES BEFORE AND AFTER MANAGEMENT UNDER SOWING FORWARD SPEED
}

\author{
Jorge W. Cortez ${ }^{1 *}$, Egas J. Armando², Anamari Viegas de A. Motomiya ${ }^{1}$, Sonia A. Rodrigues ${ }^{1}$, \\ Eduardo A. Gonçalves ${ }^{1}$
}

${ }^{1 *}$ Corresponding author. Universidade Federal da Grande Dourados/ Dourados - MS, Brasil.

E-mail: jorgewcortez@gmail.com | ORCID ID: http://orcid.org/0000-0003-1120-719X

\section{KEYWORDS}

subsoiling, conventional tillage, no-tillage.

\begin{abstract}
The soil management system affects physical attributes, and the forward sowing speed can increase or decrease its results. Thus, this work aimed to evaluate management systems before and after soil mobilisation and forward sowing speed on soil physical attributes. Thus, an experiment was conduct in a completely randomized block design with four replications and six soil management systems: no tillage (NT), medium harrowing $(\mathrm{MH})$, subsoiling operation $(\mathrm{S})$, subsoiling and medium harrowing operations $(\mathrm{S}+\mathrm{MH})$, crosssubsoiling and medium harrowing $(\mathrm{S}+\mathrm{MH})$, and ploughing and two medium harrowing $(\mathrm{P}+2 \mathrm{MH})$, and four forward sowing speeds: $3.1,5.1,5.8$, and $7.9 \mathrm{~km} \mathrm{~h}^{-1}$, applied in the subplots. Soil management affects soil penetration resistance (PR) values, pointing out the highest PR occurring in no-tillage beyond critical limits. Soil bulk density (sD) is affected by management and forward sowing speeds. The medium harrowing operation has higher $\mathrm{sD}$ and the ideal forward sowing speed range to mitigate this effect would be 5.0 to 7.0 $\mathrm{km} \mathrm{h}^{-1}$. Moreover, it also presents a higher amount of macropores in the $0.20-0.30 \mathrm{~m}$ layer. Management system without soil mobilisation favours an increase in soil microporosity, and the use of subsoiler as tillage equipment should be carried out at slower speeds to favour the increased micropores.
\end{abstract}

\section{INTRODUCTION}

Understanding the effects of soil management systems on soil quality indicators is essential to improve soil quality attributes. Soil management systems aim to establish adequate soil conditions in order to increase crop yield (Bünemann et al., 2018).

Soil management system under direct sowing has been increasing the farming area over the years due to the ability to ease farming, erosion reduction, and soil leaching. No-tillage soil management system keeps the straw of the previous crop on the soil, provides a higher percentage of soil coverage, enabling an increase in water infiltration, increases soil retention moisture, as well as improves yield (Freitas et al., 2017).

The adoption of no-tillage in detriment to conventional tillage has been highlighted due to its contribution to improving soil physical, chemical, and biological characteristics, as well as promoting an increase in organic matter on the soil surface and reduction of gas emissions and the greenhouse effect (Oliveira et al., 2015; Santos et al., 2017). The adoption of less conservationist practices can lead to an increase in soil bulk density and a decrease in macroporosity and total porosity, among other damages that can affect soil and crop attributes (Freitas et al., 2017), which are the main attributes indicated to evaluate soil management systems.

An appropriated plant stand and uniformity of seed distribution during sowing operation are pointed out as the variables of high influence on yield. These factors can be affected by numerous variables, being sowing forward speed one of the most important variables (Reynaldo et al., 2016b). Several studies have shown that an increased seeder forward speed with pneumatic dosing mechanism did not affect the longitudinal distribution of seeds and yield (Castela Junior et al., 2014), but opposite results have shown that forward speeds above $6 \mathrm{~km} \mathrm{~h}^{-1}$ can decrease crop yield up to $11.8 \%$ (Reynaldo et al., 2016a).

\footnotetext{
${ }^{1}$ Universidade Federal da Grande Dourados/ Dourados - MS, Brasil.

${ }^{2}$ Universidade Eduardo Mondlane - Escola Superior de Desenvolvimento Rural / Vilankulo, Moçambique.

Received in: 12-3-2018
}

Accepted in: 7-25-2019 
Thus, current researches are not conclusive about the adequate forward sowing speed that enables an optimal speed for a particular type of soil management to increase soybean yield without compromising soil physical attributes and crop agronomic attributes (Blum et al., 2014). Thus, it is assumed that soil management systems will interfere with soil physical attributes and an increase in sowing forward speed may negatively affect soil physical attributes. Therefore, this study aimed to evaluate the effects caused by soil management systems before and after tillage and sowing forward speed on soil physical attributes.

\section{MATERIAL AND METHODS}

This study was conducted at the Experimental Farm of Agricultural Sciences of the Federal University of Grande Dourados (UFGD), located in Dourados, MS, Brazil. The farm is located at a latitude of $22^{\circ} 14^{\prime} \mathrm{S}$ and longitude of $54^{\circ} 59^{\prime} \mathrm{W}$, with an elevation of $434 \mathrm{~m}$. The climate is type Am, i.e., a monsoon climate with dry winter, annual mean precipitation of $1500 \mathrm{~mm}$, and a mean temperature of $22{ }^{\circ} \mathrm{C}$. The soil of the area is a Rhodic Distroferric (Embrapa, 2013). Table 1 shows the particle size analysis of soil and particle bulk density of the sample area.

TABLE 1. Fertility, particle size, and particle density (PD) of the Red Latosol in the Experimental Farm of UFGD, Dourados.

\begin{tabular}{|c|c|c|c|c|}
\hline Layer & Clay & Silt & Sand & PD \\
\hline (m) & \multicolumn{3}{|c|}{ 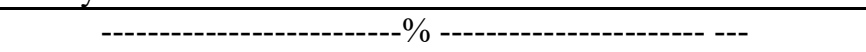 } & $\mathrm{g} \mathrm{cm}^{-3}$ \\
\hline $0.00-0.10$ & 59.7 & 21.7 & 18.4 & 2.7 \\
\hline $0.10-0.20$ & 59.2 & 22.2 & 18.5 & 2.6 \\
\hline $0.20-0.30$ & 62.3 & 19.7 & 17.9 & 2.8 \\
\hline \multirow[t]{2}{*}{$0.30-0.40$} & 62.8 & 20.2 & 16.9 & 2.7 \\
\hline & \multicolumn{4}{|c|}{ Fertility } \\
\hline Layers (m) & $\mathrm{pH} \mathrm{H} \mathrm{H}_{2} \mathrm{O}$ & $\mathrm{SB}\left(\mathrm{mmol} \mathrm{dm}^{-3}\right)$ & $\mathrm{CEC}\left(\mathrm{mmol} \mathrm{dm}{ }^{-3}\right)$ & $\mathrm{V} \%$ \\
\hline $0.00-0.10$ & 5.36 & 85.10 & 125.90 & 67.44 \\
\hline
\end{tabular}

SB: sum of bases; CEC: cation exchange capacity at $\mathrm{pH} 7.0$; V: soil base saturation. Source: particle size and particle density adapted from Rodrigues et al. (2017); soil fertility adapted from Castilho et al. (2017).

The meteorological data during the experimental period were obtained from Embrapa Western Agriculture weather station (temperatures), and the precipitation data were obtained from a rain gauge placed on the UFGD experimental farm (Figure 1).
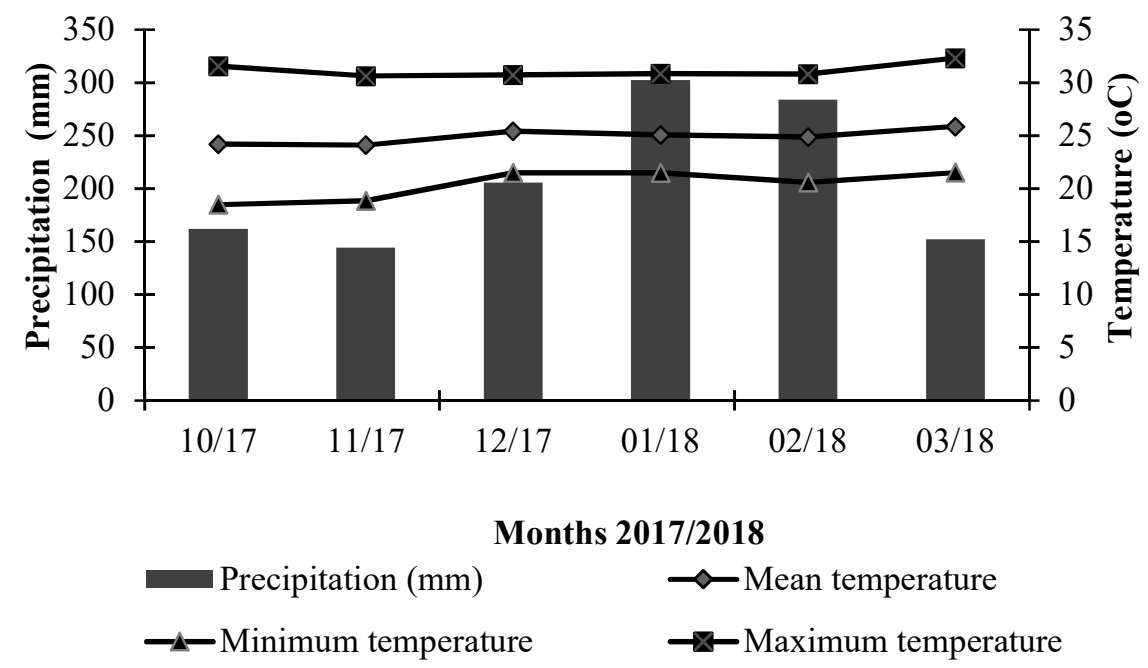

FIGURE 1. Monthly meteorological data (precipitation obtained from the experimental farming and temperature from Embrapa Western Agriculture) from 2016 to 2017.

The experiment was based on a randomised block design in a split-plot scheme, with four replications (blocks). Treatments consisted of six soil management systems: 5-year no-tillage (NT), medium harrowing (MH), subsoiling operation (S), subsoiling operation and medium harrowing $(\mathrm{S}+\mathrm{MH})$, cross-subsoiling and medium harrowing $(\mathrm{CS}+\mathrm{MH})$, and ploughing and two medium harrowing operations $(\mathrm{P}+2 \mathrm{MH})$.

Forward sowing speeds were performed in the subplots at sowing time and were obtained by gear shifting ( $\mathrm{L}$ - low gear and $\mathrm{H}$ - high gear), resulting in mean speeds of $2 \mathrm{~L}=3.1,2 \mathrm{H}=5.1,3 \mathrm{~L}=5.8$, and $3 \mathrm{H}=7.9 \mathrm{~km} \mathrm{~h}^{-1}$.

Each experimental plot occupied an area of $15 \times 20$ $\mathrm{m}\left(300 \mathrm{~m}^{2}\right)$. In the longitudinal direction between plots, a space of $12 \mathrm{~m}$ was reserved for turnovers, machinery traffic, and stabilisation of machinery sets. Soil management was performed on October 25, 2017.

Penetration resistance (PR) was performed with an IAA/Planalsucar-Stolf impact penetrometer adapted by KAMAQ and cited by Stolf et al. (2012). PR was evaluated before soil management and after harvest $(10 / 22 / 2017$ and $03 / 03 / 2018$, respectively) at eight points spaced $1 \mathrm{~m}$ from each other for each depth $(0.00-0.10$, 
$0.01-0.20,0.20-0.30$, and $0.30-0.40 \mathrm{~m})$, totalling 32 sampling points per plot, corresponding to 768 points in the entire area. The values obtained from the successive counting of penetrometer impacts were transformed into dynamic strength (MPa), as in Stolf (1991).

Soil water content was determined by disturbed samples collected before and after management $(10 / 22 / 2017$ and $03 / 05 / 2018$, respectively) at depths of
$0.00-0.10,0.01-0.20,0.20-0.30$, and $0.30-0.40 \mathrm{~m}$ in the centre of each plot by the gravimetric method (Donagema et al., 2011). A sample point was collected per plot at the four depths, totalling 96 individual samples, being formed 24 composite samples (Table 2). Subsequently, composite samples were oven-dried for $24 \mathrm{~h}$ at $105{ }^{\circ} \mathrm{C}$ to determine soil water content, according to the methodology of Donagema et al. (2011).

TABLE 2. Soil water content at the time of penetration resistance measurement before and after soil management

\begin{tabular}{lcccccccc}
\hline \multirow{2}{*}{ Factor } & \multicolumn{7}{c}{ Water content $(\%)$} \\
\cline { 2 - 9 } & \multicolumn{2}{c}{$0.0-0.10 \mathrm{~m}$} & \multicolumn{2}{c}{$0.10-0.20 \mathrm{~m}$} & \multicolumn{2}{c}{$0.20-0.30 \mathrm{~m}$} & \multicolumn{2}{c}{$0.30-0.40 \mathrm{~m}$} \\
\hline Management (M) & Before & After & Before & After & Before & After & Before & After \\
\hline S & 28.13 & 28.95 & 29.00 & 27.97 & 31.79 & 33.03 & 33.03 & 30.86 \\
CS+MH & 29.07 & 28.21 & 27.80 & 30.68 & 29.10 & 27.74 & 28.82 & 30.14 \\
S+MH & 28.42 & 29.36 & 29.34 & 28.34 & 33.08 & 28.99 & 30.43 & 29.93 \\
MH & 30.81 & 30.18 & 29.24 & 29.00 & 31.79 & 30.19 & 30.30 & 31.05 \\
NT & 30.81 & 29.02 & 29.99 & 28.68 & 31.09 & 28.71 & 29.92 & 30.56 \\
P+2MH & 30.75 & 28.86 & 28.74 & 26.96 & 30.58 & 26.41 & 29.65 & 30.00 \\
\hline
\end{tabular}

No-tillage (NT); medium harrowing (MH); subsoiling (S); subsoiling + medium harrowing $(\mathrm{S}+\mathrm{MH})$; cross-subsoiling + medium harrowing $(\mathrm{SC}+\mathrm{MH})$; ploughing and two medium harrowing $(\mathrm{P}+2 \mathrm{MH})$.

Moreover, undisturbed soil samples were collected (10/20/2017 and 03/02/2018, respectively) and subjected to laboratory analysis to determine soil bulk density, macroporosity, microporosity, and total porosity (Donagema et al., 2011). Samples were collected from each plot (management) using volumetric rings with a volume of $98 \mathrm{~cm}^{3}$. Soil samples were collected at a random point within each plot in the interrows at depths of 0.00 $0.10,0.01-0.20,0.20-0.30$, and $0.30-0.40 \mathrm{~m}$.

The data were submitted to analysis of variance and, when significant, to the Scott-Knott test at 5\% probability to compare the means of soil attributes. Treatments in which the forward sowing speed (quantitative variable) presented a significant effect were sliced, and a polynomial regression analysis was performed, with graphs only for linear, quadratic, or cubic regression that presented significance.

\section{RESULTS AND DISCUSSION}

Soil management systems had a significant effect for PR in the $0.0-0.10,0.10-0.20$, and $0.20-0.30 \mathrm{~m}$ layers before the management and in the $0.0-0.10 \mathrm{~m}$ layer after management (Table 3). Bulk density had a significant effect in the $0.20-0.30 \mathrm{~m}$ layer before the management and a significant interaction management $\mathrm{x}$ speed. Macroporosity showed a significant effect in the $0.10-0.20$ $\mathrm{m}$ layer before and after management, and in the $0.20-0.30$ $\mathrm{m}$ layer for the interaction management and speed. Microporosity presented a significant effect in the 0.10 $0.20,0.20-0.30$, and $0.30-0.40 \mathrm{~m}$ layers after management and in the interaction management system and sowing forward speed for the $0.20-0.30 \mathrm{~m}$ layer. The total porosity had no significant effect on any treatment (Table 3 ). The factor forward sowing speed, in isolation, did not affect any of the attributes and layers, and its effect was associated only with some management systems. The nonsignificant effect in the forward sowing speed could be associated with a lower machinery traffic time in the area and a higher operating performance of the implement.

The coefficient of variation (CV) can be classified as low when it is below $10 \%$, medium from 10 to $20 \%$, high from 20 to $30 \%$, and very high above $30 \%$ (Frederico-Gomes \& Garcia, 2002). The highest values of coefficient of variation were found for the attribute macroporosity (Table 3 ), having its value reduced after management, but remaining with very high values. For the other attributes, the reduction ratio of $\mathrm{CV}$ after management was isolated in some layers, with no generalisation. 
TABLE 3. Analysis of variance and coefficient of variation for soil penetration resistance (PR), soil bulk density (SD), macroporosity (Macro), microporosity (Micro), and total porosity (TP) before and after management.

\begin{tabular}{|c|c|c|c|c|c|c|c|}
\hline \multirow[b]{2}{*}{ Attribute/Layer (m) } & \multicolumn{4}{|c|}{ F-test } & \multicolumn{2}{|c|}{ CV (\%) } & \multirow[b]{2}{*}{$\begin{array}{c}\text { Forward } \\
\text { speed }\end{array}$} \\
\hline & $\begin{array}{c}\text { Management } \\
\text { Before }\end{array}$ & $\begin{array}{l}\text { Management } \\
\text { After }\end{array}$ & $\begin{array}{l}\text { Forward } \\
\text { speed }\end{array}$ & $\begin{array}{l}\text { Management } \mathrm{x} \\
\text { forward speed }\end{array}$ & $\begin{array}{c}\text { Before } \\
\text { management }\end{array}$ & $\begin{array}{c}\text { After } \\
\text { management }\end{array}$ & \\
\hline$R P-0.00-0.10$ & $4.52 *$ & $7.62 * *$ & $0.37^{\mathrm{ns}}$ & $1.28^{\mathrm{ns}}$ & 18.90 & 12.46 & 18.34 \\
\hline$R P-0.10-0.20$ & $3.73^{*}$ & $1.47^{\mathrm{ns}}$ & $0.31^{\mathrm{ns}}$ & $0.44^{\mathrm{ns}}$ & 17.10 & 24.93 & 21.28 \\
\hline$R P-0.20-0.30$ & $4.40^{*}$ & $1.74^{\mathrm{ns}}$ & $1.07^{\mathrm{ns}}$ & $1.70^{\mathrm{ns}}$ & 15.35 & 25.75 & 19.41 \\
\hline $\mathrm{RP}-0.30-0.40$ & $1.82^{\mathrm{ns}}$ & $0.80^{\mathrm{ns}}$ & $1.03^{\mathrm{ns}}$ & $1.21^{\mathrm{ns}}$ & 26.67 & 35.44 & 20.54 \\
\hline$\overline{\mathrm{DS}}-0.00-0.10$ & $0.91^{\mathrm{ns}}$ & $0.24^{\mathrm{ns}}$ & $1.18^{\mathrm{ns}}$ & $1.03^{\mathrm{ns}}$ & 10.32 & 14.45 & 13.56 \\
\hline $\mathrm{DS}-0.10-0.20$ & $1.32^{\mathrm{ns}}$ & $1.19^{\mathrm{ns}}$ & $0.36^{\mathrm{ns}}$ & $0.66^{\mathrm{ns}}$ & 7.07 & 12.87 & 13.12 \\
\hline $\mathrm{DS}-0.20-0.30$ & $3.48^{*}$ & $1.29^{\mathrm{ns}}$ & $1.40^{\mathrm{ns}}$ & $2.35^{*}$ & 5.92 & 7.76 & 8.67 \\
\hline $\mathrm{DS}-0.30-0.40$ & $1.54^{\mathrm{ns}}$ & $0.21^{\mathrm{ns}}$ & $0.02^{\mathrm{ns}}$ & $1.13^{\mathrm{ns}}$ & 5.89 & 8.61 & 9.62 \\
\hline Macro $-0.00-0.10$ & $0.41^{\mathrm{ns}}$ & $1.85^{\mathrm{ns}}$ & $0.27^{\mathrm{ns}}$ & $1.01^{\mathrm{ns}}$ & 66.75 & 40.64 & 54.87 \\
\hline Macro - 0.10-0.20 & $4.22 *$ & $3.16^{*}$ & $0.43^{\mathrm{ns}}$ & $0.66^{\mathrm{ns}}$ & 64.73 & 43.73 & 55.47 \\
\hline Macro - 0.20-0.30 & $0.67^{\text {ns }}$ & $0.57^{\mathrm{ns}}$ & $1.45^{\mathrm{ns}}$ & $1.95^{*}$ & 73.82 & 54.21 & 43.09 \\
\hline Macro - 0.30-0.40 & $3.27^{\mathrm{ns}}$ & $2.26^{\mathrm{ns}}$ & $0.99^{\text {ns }}$ & $0.70^{\mathrm{ns}}$ & 71.85 & 47.67 & 54.01 \\
\hline Micro - 0.00-0.10 & $2.70^{\mathrm{ns}}$ & $0.71^{\mathrm{ns}}$ & $1.28^{\mathrm{ns}}$ & $0.58^{\mathrm{ns}}$ & 7.51 & 14.09 & 13.83 \\
\hline Micro - 0.10-0.20 & $1.57^{\mathrm{ns}}$ & $3.38^{*}$ & 0.73 ns & $1.14^{\mathrm{ns}}$ & 7.61 & 10.69 & 12.02 \\
\hline Micro - 0.20-0.30 & $1.30^{\mathrm{ns}}$ & $4.57 * *$ & $1.56^{\mathrm{ns}}$ & $2.26^{*}$ & 11.25 & 5.91 & 8.66 \\
\hline Micro - 0.30-0.40 & $1.05^{\mathrm{ns}}$ & $3.58^{*}$ & $0.46^{\mathrm{ns}}$ & $0.92^{\mathrm{ns}}$ & 5.76 & 9.09 & 8.88 \\
\hline $\mathrm{TP}-0.00-0.10$ & $0.18^{\mathrm{ns}}$ & $1.42^{\mathrm{ns}}$ & $1.36^{\mathrm{ns}}$ & $1.52^{\mathrm{ns}}$ & 14.12 & 9.93 & 12.53 \\
\hline $\mathrm{TP}-0.10-0.20$ & $1.68^{\mathrm{ns}}$ & $2.80^{\mathrm{ns}}$ & $1.78^{\mathrm{ns}}$ & $1.09^{\mathrm{ns}}$ & 9.04 & 11.39 & 9.67 \\
\hline $\mathrm{TP}-0.20-0.30$ & $0.27^{\mathrm{ns}}$ & $0.62^{\mathrm{ns}}$ & $0.30^{\mathrm{ns}}$ & $1.30^{\mathrm{ns}}$ & 12.65 & 10.83 & 7.45 \\
\hline $\mathrm{TP}-0.30-0.40$ & $3.11^{\mathrm{ns}}$ & $0.84^{\mathrm{ns}}$ & $0.62^{\mathrm{ns}}$ & $0.72^{\mathrm{ns}}$ & 9.32 & 10.38 & 8.00 \\
\hline
\end{tabular}

No-tillage (NT); medium harrowing (MH); subsoiling (S); subsoiling + medium harrowing $(\mathrm{S}+\mathrm{MH})$; cross-subsoiling + medium harrowing $(\mathrm{SC}+\mathrm{MH})$; ploughing + two medium harrowing $(\mathrm{P}+2 \mathrm{MH})$.

Although the F-test was significant to PR before management for the first three layers, no significant difference was observed in the mean values (Table 4). It occurs because they are different tests, and the same happens to soil bulk density before soil management in the $0.20-0.30 \mathrm{~m}$ layer. Additionally, no significant difference was observed for macroporosity before and after management in the $0.10-0.20 \mathrm{~m}$ layer and for microporosity in the $0.10-0.20 \mathrm{~m}$ layer after management.

After management, PR in the $0.0-0.10 \mathrm{~m}$ layer was higher in the no-tillage (NT) area due to the lack of machine mobilisation and traffic (Table 4). In general, a reduction was observed in PR after management, which was also verified for soil bulk density. It shows that the lack of soil management in the area increases soil surface compaction, showing that the soil under NT management maintains its compaction level over time (Moraes et al., 2014). PR values after management (four and a half months later) in the 0.00 $0.10 \mathrm{~m}$ layer remained above the critical limit (2.0 MPa) for $\mathrm{P}+2 \mathrm{MH}$, indicating no effect of conventional soil tillage for a long time. It may be associated with the higher precipitation recorded during the season, which may have contributed to the natural soil drift, while the other management systems presented acceptable values when considering a critical PR of 3.0 MPa for reduced tillage and 3.5 MPa for no-tillage system (NT), showing the contribution of reduced tillage and non-mobilization for soil compaction management (Baia et al., 2018). 
TABLE 4. Soil penetration resistance (PR, MPa), soil bulk density (SD, $\mathrm{kg} \mathrm{dm}^{-3}$ ), macroporosity (Macro, \%), microporosity (Micro, \%), and total porosity (TP, \%) before and after management.

\begin{tabular}{|c|c|c|c|c|c|c|c|c|c|c|}
\hline \multirow[t]{3}{*}{ Factor } & \multicolumn{2}{|c|}{ PR } & \multicolumn{2}{|c|}{ SD } & \multicolumn{2}{|c|}{ Macro } & \multicolumn{2}{|c|}{ Micro } & \multicolumn{2}{|c|}{ PT } \\
\hline & Before & After & Before & After & Before & After & Before & After & Before & After \\
\hline & \multicolumn{10}{|c|}{$0,0-0,10 \mathrm{~m}$} \\
\hline $\mathrm{S}$ & $3.77 \mathrm{a}$ & $2.37 \mathrm{~b}$ & 1.37 & 1.16 & 7.91 & 23.51 & 38.68 & 38.65 & 46.59 & 62.16 \\
\hline $\mathrm{SC}+\mathrm{MH}$ & $4.12 \mathrm{a}$ & $2.42 \mathrm{~b}$ & 1.41 & 1.20 & 5.90 & 20.35 & 41.23 & 40.24 & 47.13 & 60.59 \\
\hline $\mathrm{S}+\mathrm{MH}$ & $4.82 \mathrm{a}$ & $2.46 \mathrm{~b}$ & 1.44 & 1.20 & 7.27 & 22.12 & 40.12 & 38.94 & 47.38 & 61.07 \\
\hline MH & $3.95 \mathrm{a}$ & $2.52 \mathrm{~b}$ & 1.34 & 1.18 & 13.71 & 22.75 & 40.72 & 38.94 & 54.43 & 61.43 \\
\hline NT & $3.55 \mathrm{a}$ & $2.92 \mathrm{a}$ & 1.33 & 1.16 & 10.57 & 21.72 & 41.25 & 41.61 & 51.82 & 63.34 \\
\hline $\mathrm{P}+2 \mathrm{MH}$ & $3.28 \mathrm{a}$ & $2.33 \mathrm{~b}$ & 1.42 & 1.21 & 8.47 & 22.75 & 43.16 & 39.13 & 51.63 & 61.97 \\
\hline Factor & \multicolumn{10}{|c|}{$0.10-0.20 \mathrm{~m}$} \\
\hline $\mathrm{S}$ & $4.74 \mathrm{a}$ & 3.01 & 1.42 & 1.23 & $10.17 \mathrm{a}$ & $10.37 \mathrm{a}$ & 41.29 & $39.31 \mathrm{a}$ & 51.45 & 49.68 \\
\hline $\mathrm{SC}+\mathrm{MH}$ & $5.10 \mathrm{a}$ & 2.62 & 1.46 & 1.30 & $7.14 \mathrm{a}$ & $9.39 \mathrm{a}$ & 40.69 & $41.54 \mathrm{a}$ & 47.83 & 50.93 \\
\hline $\mathrm{S}+\mathrm{MH}$ & $5.58 \mathrm{a}$ & 2.69 & 1.46 & 1.23 & $4.98 \mathrm{a}$ & $15.47 \mathrm{a}$ & 42.77 & $39.45 \mathrm{a}$ & 47.75 & 54.92 \\
\hline MH & $5.29 \mathrm{a}$ & 3.21 & 1.43 & 1.30 & $7.10 \mathrm{a}$ & $9.96 \mathrm{a}$ & 41.89 & $40.89 \mathrm{a}$ & 48.98 & 50.85 \\
\hline NT & $4.84 \mathrm{a}$ & 3.01 & 1.36 & 1.21 & $5.36 \mathrm{a}$ & $11.71 \mathrm{a}$ & 40.52 & $44.15 \mathrm{a}$ & 45.89 & 55.86 \\
\hline $\mathrm{P}+2 \mathrm{MH}$ & $4.67 \mathrm{a}$ & 2.92 & 1.44 & 1.20 & $7.59 \mathrm{a}$ & $12.75 \mathrm{a}$ & 41.23 & $38.73 \mathrm{a}$ & 48.82 & 51.49 \\
\hline Factor & \multicolumn{10}{|c|}{$0.20-0.30 \mathrm{~m}$} \\
\hline $\mathrm{S}$ & $4.33 \mathrm{a}$ & 2.94 & $1.36 \mathrm{a}$ & 1.28 & 7.28 & 13.99 & 43.07 & $43.19 \mathrm{~b}$ & 50.34 & 57.18 \\
\hline $\mathrm{SC}+\mathrm{MH}$ & $4.04 \mathrm{a}$ & 3.07 & $1.47 \mathrm{a}$ & 1.27 & 7.97 & 16.05 & 42.63 & $42.37 \mathrm{~b}$ & 50.60 & 58.42 \\
\hline $\mathrm{S}+\mathrm{MH}$ & $4.55 \mathrm{a}$ & 3.09 & $1.34 \mathrm{a}$ & 1.23 & 5.41 & 14.98 & 44.36 & $40.92 \mathrm{~b}$ & 49.77 & 55.89 \\
\hline MH & $4.76 \mathrm{a}$ & 3.47 & $1.36 \mathrm{a}$ & 1.29 & 6.09 & 14.98 & 43.28 & $42.15 \mathrm{~b}$ & 49.37 & 57.12 \\
\hline NT & $4.61 \mathrm{a}$ & 3.16 & $1.33 \mathrm{a}$ & 1.22 & 10.62 & 14.70 & 41.42 & $44.89 \mathrm{a}$ & 52.04 & 59.59 \\
\hline $\mathrm{P}+2 \mathrm{MH}$ & $4.19 \mathrm{a}$ & 3.66 & $1.38 \mathrm{a}$ & 1.24 & 7.88 & 15.88 & 42.11 & $41.98 \mathrm{~b}$ & 50.00 & 57.86 \\
\hline Factor & \multicolumn{10}{|c|}{$0.30-0.40 \mathrm{~m}$} \\
\hline $\mathrm{S}$ & 3.78 & 3.77 & 1.38 & 1.27 & 4.52 & 8.13 & $45.64 \mathrm{a}$ & $44.44 \mathrm{a}$ & 50.15 & 58.95 \\
\hline $\mathrm{SC}+\mathrm{MH}$ & 3.84 & 3.24 & 1.42 & 1.26 & 7.94 & 11.06 & $40.78 b$ & $41.58 \mathrm{~b}$ & 48.73 & 58.11 \\
\hline $\mathrm{S}+\mathrm{MH}$ & 4.60 & 3.38 & 1.39 & 1.28 & 10.32 & 12.27 & $41.94 \mathrm{~b}$ & $41.78 \mathrm{~b}$ & 52.26 & 56.85 \\
\hline MH & 5.21 & 3.26 & 1.31 & 1.26 & 4.58 & 11.59 & $39.75 b$ & $42.24 \mathrm{~b}$ & 44.33 & 57.26 \\
\hline NT & 4.18 & 2.97 & 1.31 & 1.24 & 3.40 & 8.34 & $39.35 b$ & $46.24 \mathrm{a}$ & 42.75 & 61.63 \\
\hline $\mathrm{P}+2 \mathrm{MH}$ & 4.02 & 3.45 & 1.41 & 1.27 & 5.79 & 8.88 & $41.78 \mathrm{~b}$ & $42.24 \mathrm{~b}$ & 47.57 & 58.02 \\
\hline
\end{tabular}

Means followed by the same lowercase letters in the column do not differ from each other by the Scott-Knott test at 5\% probability. Notillage $(\mathrm{NT})$; medium harrowing $(\mathrm{MH})$; subsoiling $(\mathrm{S})$; subsoiling + medium harrowing $(\mathrm{S}+\mathrm{MH})$; cross-subsoiling + medium harrowing $(\mathrm{SC}+\mathrm{MH})$; ploughing + two medium harrowing $(\mathrm{P}+2 \mathrm{MH})$.

The PR data can be classified according to Moraes et al. (2014), who set the critical limit of $2.0 \mathrm{MPa}$ for conventional tillage, 3.0 MPa for minimum tillage, and 3.5 MPa for no-tillage system in most crops. Thus, although the value of $2 \mathrm{MPa}$ is more commonly adopted as a limit to root growth, the possibility of increasing the critical threshold of penetration resistance to $3.5 \mathrm{MPa}$ in terms of non-mobilization of soil is due to the presence of continuous and biological pores, which favour root growth even in areas with high PR values (Moraes et al., 2014).

Moreover, the higher PR value should be accepted in areas with non-mobilization of soil since machinery traffic favour the highest PR value in the $0.00-0.20 \mathrm{~m}$ surface layers (Cortez et al., 2017).

Thus, the effect of soil tillage was beneficial on the topsoil and maintained critical penetration resistance levels for satisfactory root development of crops, which vary according to management, soil type, and crop species (Cortez et al., 2017; Girardello et al., 2017).

Soil bulk density ranged from 1.31 to $1.47 \mathrm{Mg} \mathrm{m}^{-3}$ before management, but after management, the values decreased to 1.16 to $1.30 \mathrm{Mg} \mathrm{m}^{-3}$ (Table 4). Soil bulk density is an excellent characteristic considered in the evaluation of soil structural state due to its correlation to soil compaction. Although management systems did not differ statistically, soil management reduced soil bulk density values of the period before management.

The critical soil bulk density for some textural classes of clay soils ranges from 1.30 to $1.40 \mathrm{Mg} \mathrm{m}^{-3}$. Additionally, in clay Oxisols, aeration deficiency starts with a soil bulk density close to $1.30 \mathrm{Mg} \mathrm{m}^{-3}$ (Santana et al., 2018). Thus, the occurrence of lower soil bulk density values in the surface layer under no-tillage can be attributed to an increase in organic matter (Assis et al., 2015).

Thus, soil bulk density before management was significant in the $0.20-0.30 \mathrm{~m}$ layer, but the values did not differ statistically from each other and were in the critical range (1.33-1.47 $\mathrm{Mg} \mathrm{m}^{-3}$ ) for root system development, which may correlate with higher PR values before management. After management, a significant effect of the interaction management system and forward sowing speed also occurred in the $0.20-0.30 \mathrm{~m}$ layer. The analysis of individual management showed that the medium harrowing at $5.1 \mathrm{~km} \mathrm{~h}^{-1}$ provided the highest $\mathrm{sD}$ value (Table 5), which is associated with the soil mobilisation 
effect caused by disc slip and ground pressure (Novak et al., 2017). A higher sD was observed under crosssubsoiling and medium harrowing, subsoiling and medium harrowing, and ploughing at a sowing speed of $5.8 \mathrm{~km} \mathrm{~h}^{-1}$ (Table 5), evidencing that even with the use of deeper action equipment, sD increases in the $0.20-0.30 \mathrm{~m}$ layer after the use of medium harrowing. The sowing forward speed analysis of each management showed that only
$\mathrm{SC}+\mathrm{MH}$ and $\mathrm{MH}$ presented a significant effect, and the regression analysis demonstrated that only $\mathrm{MH}$ was significant for the cubic regression (Figure 2), in which a tendency of $\mathrm{sD}$ reduction was observed in the sowing forward speed range of 5 to $7 \mathrm{~km} \mathrm{~h}^{-1}$. Usually, an increase in sowing forward speed provides shorter compression time and, consequently, lower $\mathrm{SD}$ and $\mathrm{PR}$ values (Mahmoudi et al., 2015).

TABLE 5. Slicing of interaction between soil management and sowing forward speed for soil bulk density ( $\left.\mathrm{sD}, \mathrm{kg} \mathrm{dm}^{-3}\right)$, macroporosity (Macro, \%), and microporosity (Micro, \%) in the 0.20-0.30 m layer.

\begin{tabular}{|c|c|c|c|c|}
\hline \multirow[b]{2}{*}{ Management } & \multicolumn{4}{|c|}{ Sowing forward speed $\left(\mathrm{km} \mathrm{h}^{-1}\right)$} \\
\hline & 3.1 & 5.1 & 5.8 & 7.9 \\
\hline & \multicolumn{4}{|c|}{ Soil bulk density $\left(\mathrm{kg} \mathrm{dm}^{-3}\right)$} \\
\hline $\mathrm{S}$ & $1.35 \mathrm{a}$ & $1.20 \mathrm{~b}$ & $1.24 \mathrm{~b}$ & $1.31 \mathrm{a}$ \\
\hline $\mathrm{SC}+\mathrm{MH}^{*}$ & $1.21 \mathrm{a}$ & $1.24 \mathrm{~b}$ & $1.41 \mathrm{a}$ & $1.22 \mathrm{a}$ \\
\hline $\mathrm{S}+\mathrm{MH}$ & $1.24 \mathrm{a}$ & $1.17 \mathrm{~b}$ & $1.32 \mathrm{a}$ & $1.20 \mathrm{a}$ \\
\hline $\mathrm{MH}^{*}$ & $1.33 \mathrm{a}$ & $1.41 \mathrm{a}$ & $1.18 \mathrm{~b}$ & $1.24 \mathrm{a}$ \\
\hline NT & $1.27 \mathrm{a}$ & $1.23 \mathrm{~b}$ & $1.24 \mathrm{~b}$ & $1.12 \mathrm{a}$ \\
\hline \multirow[t]{2}{*}{$\mathrm{P}+2 \mathrm{MH}$} & $1.12 \mathrm{a}$ & $1.24 \mathrm{~b}$ & $1.33 \mathrm{a}$ & $1.26 \mathrm{a}$ \\
\hline & \multicolumn{4}{|c|}{ Soil macroporosity (\%) } \\
\hline S & $8.31 \mathrm{a}$ & $10.13 \mathrm{a}$ & $8.90 \mathrm{~b}$ & $9.37 \mathrm{a}$ \\
\hline $\mathrm{SC}+\mathrm{MH}^{*}$ & $15.36 \mathrm{a}$ & $13.90 \mathrm{a}$ & $5.89 \mathrm{~b}$ & $12.04 \mathrm{a}$ \\
\hline $\mathrm{S}+\mathrm{MH}^{*}$ & $7.20 \mathrm{a}$ & $16.08 \mathrm{a}$ & $9.48 \mathrm{~b}$ & $14.47 \mathrm{a}$ \\
\hline $\mathrm{MH}^{*}$ & $7.84 \mathrm{a}$ & $6.92 \mathrm{a}$ & $16.10 \mathrm{a}$ & $10.63 \mathrm{a}$ \\
\hline NT & $9.73 \mathrm{a}$ & $9.87 \mathrm{a}$ & $8.47 \mathrm{~b}$ & $11.61 \mathrm{a}$ \\
\hline \multirow[t]{2}{*}{$\mathrm{P}+2 \mathrm{MH}$} & $9.86 \mathrm{a}$ & $11.77 \mathrm{a}$ & $7.44 \mathrm{~b}$ & $10.78 \mathrm{a}$ \\
\hline & \multicolumn{4}{|c|}{ Soil microporosity (\%) } \\
\hline $\mathrm{S}^{*}$ & $48.48 \mathrm{a}$ & $41.40 \mathrm{~b}$ & $40.81 \mathrm{~b}$ & $42.04 \mathrm{a}$ \\
\hline $\mathrm{SC}+\mathrm{MH}$ & $40.24 \mathrm{~b}$ & $41.75 \mathrm{~b}$ & $46.66 \mathrm{a}$ & $40.83 \mathrm{a}$ \\
\hline $\mathrm{S}+\mathrm{MH}$ & $42.85 \mathrm{~b}$ & $38.19 \mathrm{~b}$ & $41.96 \mathrm{~b}$ & $40.65 \mathrm{a}$ \\
\hline MH & $44.74 \mathrm{a}$ & $44.60 \mathrm{a}$ & $39.25 \mathrm{~b}$ & $39.98 \mathrm{a}$ \\
\hline NT & $44.37 \mathrm{a}$ & $47.22 \mathrm{a}$ & $45.34 \mathrm{a}$ & $42.60 \mathrm{a}$ \\
\hline $\mathrm{P}+2 \mathrm{MH}$ & $40.15 b$ & $39.98 \mathrm{~b}$ & $45.24 \mathrm{a}$ & $42.51 \mathrm{a}$ \\
\hline
\end{tabular}

Means followed by lowercase letters in the column do not differ from each other by the Scott-Knott test at 5\% probability. No-tillage (NT); medium harrowing $(\mathrm{MH})$; subsoiling $(\mathrm{S})$; subsoiling + medium harrowing $(\mathrm{S}+\mathrm{MH})$; cross-subsoiling + medium harrowing $(\mathrm{SC}+\mathrm{MH})$; ploughing + two medium harrowing $(\mathrm{P}+2 \mathrm{MH}) .{ }^{*}$ Significant effect of sowing forward speed on management; in this case, a regression analysis was performed.

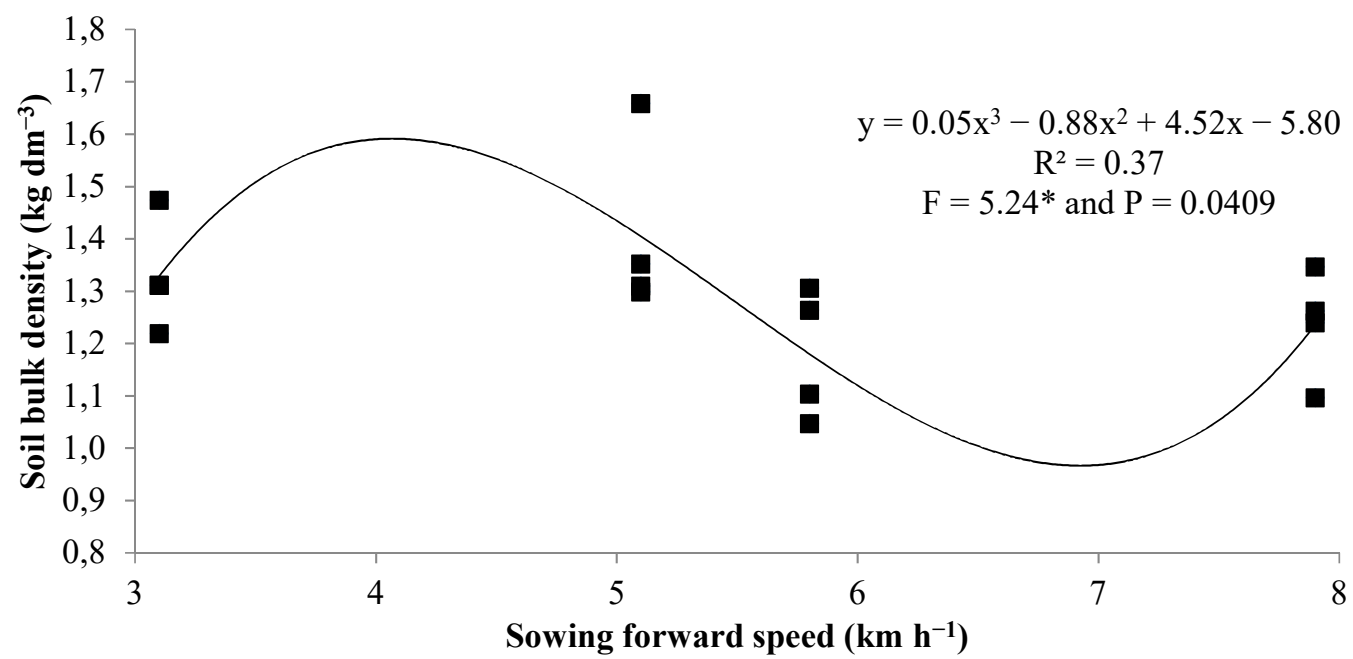

FIGURE 2. Regression analysis for soil bulk density in the $0.20-0.30 \mathrm{~m}$ layer under sowing forward speed for medium harrowing. *Significant at $1 \%$ probability. F: calculated $\mathrm{F}$ and $\mathrm{P}$ : probability. 
For macroporosity, the mean values of soil management systems were statistically equal in the 0.10 $0.20 \mathrm{~m}$ layer (Table 4), which is justified due to the use of the F-test and then the test of means. The mean value of macropores ranged from 3.4 to $13.71 \%$ before management, but after mobilisation operations, it increased from 8.13 to $23.51 \%$, evidencing an increase in macropores. Macropores are related to vital processes for plant roots, especially for respiration, and management must ensure their maintenance and preservation (Sales et al., 2016).

Soil management systems increased macroporosity values at all depths when compared to the period before management, with increasing values up to a depth of 0.20 $\mathrm{m}$ and decreasing values at depths from 0.20 to $0.40 \mathrm{~m}$ in relation to minimum values. Therefore, soil management increased macropores values, making them adequate for root development, especially for deeper layers, once, for the soil becomes physically suitable for plant growth, it must have at least $10 \%$ of macropores to maintain adequate aeration levels (Sales et al., 2016).

The higher percentage of macropores in NT was observed by Silva et al. (2014), which is different from that observed in this study, and concluded that disturbed soils have higher percentage of macropore values in the $0.00-0.40 \mathrm{~m}$ layer, causing higher water infiltration speed and aeration.

The interaction between management and speed for macropores was significant for the $0.20-0.30 \mathrm{~m}$ layer (Table 5). Only the sowing forward speed of $5.8 \mathrm{~km} \mathrm{~h}^{-1}$ affected the percentage of macropores, with the highest value under the use of medium harrowing due to its action of soil mobilisation, destroying clods and levelling the terrain. Sowing forward speed in management with $\mathrm{SC}+\mathrm{MH}, \mathrm{S}+\mathrm{MH}$, and $\mathrm{MH}$ had significant effect (Table 5), but the regression analysis showed no significant effect for linear, quadratic or cubic regressions.
Microporosity in the $0.20-0.30 \mathrm{~m}$ layer after management was higher in NT (Table 4), which is due to higher compaction, in which macropores was transformed into micropores. On the other hand, the $0.30-0.40 \mathrm{~m}$ layer showed again higher values in the NT and S (subsoiling) areas. The $0.10-0.20 \mathrm{~m}$ layer did not affect the test of means, which were equal. Soil mobilisation promoted a decrease in the percentage of micropores to the detriment of macropores, making the soil with lower water holding capacity and gas flow, which could lead to a fast water deficit for crops (Luciano et al., 2014). Moreover, it may also decrease soil moisture, corroborating the results obtained by Oliveira et al. (2015). However, these authors found a smaller proportion of macropores and micropores in the surface layers $(0.00-0.20 \mathrm{~m})$.

The analysis of the interaction between management and forward sowing speed showed that microporosity had an effect at $3.1,5.1$, and $5.8 \mathrm{~km} \mathrm{~h}^{-1}$ (Table 5). The highest microporosity values were observed at the lowest sowing forward speed for S, MH, and NT, while $\mathrm{MH}$ and NT showed the highest values at the sowing forward speed $5.1 \mathrm{~km} \mathrm{~h}^{-1}$. In addition, the management $\mathrm{SC}+\mathrm{MH}, \quad \mathrm{NT}$, and $\mathrm{P}+2 \mathrm{MH}$ presented the highest microporosity values at the sowing forward speed of 5.8 $\mathrm{km} \mathrm{h}^{-1}$. The increased microporosity under cross-subsoiling may be associated with a deeper working depth of the subsoiler (Santana et al., 2018).

Individually, only the management with S (Table 5) presented effect for sowing forward speeds. The regression analysis (Figure 3) demonstrated a quadratic adjustment for microporosity data, and lower sowing forward speeds enabled higher values of micropores up to a speed of approximately $6.5 \mathrm{~km} \mathrm{~h}^{-1}$, increasing again from this point. Thus, the subsoiler must work at lower speeds to provide larger micropores in depth.

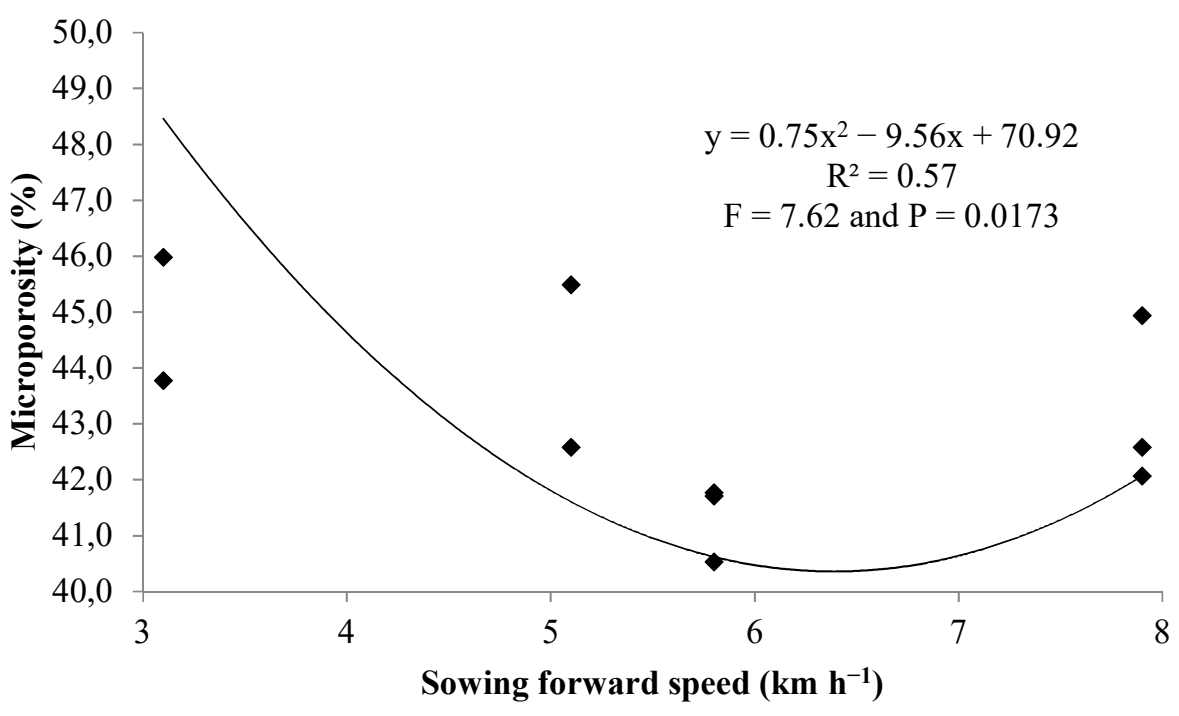

FIGURE 3. Regression analysis for soil microporosity in the $0.20-0.30 \mathrm{~m}$ layer as a function of sowing forward speed for medium harrowing. *Significant at $1 \%$ probability. $\mathrm{F}$ : calculated $\mathrm{F}$ and $\mathrm{P}$ : probability. 
Soil management, in general, increased the total porosity (Table 4 ), making it a non-restrictive interval (higher than 50\%) for legume root system growth in all management systems for dystrophic Red Latosols (Santana et al., 2018). The surface layer presented the highest amount of total porosity because it is the layer with the highest mobilisation action of tillage equipment. Soil mobilisation in deeper layers can decrease the total porosity, which may be related to the pressure exerted by active organs of the equipment used in operation.

\section{CONCLUSIONS}

Soil management affects penetration resistance (PR), in which the highest PR values (higher than critical limits) occurs in systems without soil mobilisation.

Soil bulk density (sD) is affected by soil management systems and sowing forward speeds. In addition, the medium harrowing soil management has higher $\mathrm{sD}$, and the ideal range to mitigate this effect would be 5.0 to $7.0 \mathrm{~km} \mathrm{~h}^{-1}$. The use of medium harrowing increases the number of macropores in the $0.20-0.30$ m layer.

Soil management system without mobilisation favours higher soil microporosity, and the use of subsoiler as tillage equipment should be carried out at lower forward speeds because it leads to an increase in the number of micropores in depth.

The use of harrower after equipment such as ploughing and subsoiler increases soil bulk density at higher depths.

\section{ACKNOWLEDGEMENTS}

To Eduardo Mondlane University and the Mozambique Institute of Scholarships for their partnership in granting a scholarship to the second author. To the Federal University of Grande Dourados Foundation (UFGD) and the Graduate Program in Agricultural Engineering of FCA.

\section{REFERENCES}

Assis PCR, Stone LF, Medeiros JC, Madari BE, Oliveira JM, Wruck FJ (2015) Atributos físicos do solo em sistemas de integração lavoura-pecuária-floresta. Revista Brasileira de Engenharia Agrícola e Ambiental 19(4):309316. DOI: http://dx.doi.org/10.1590/1807-

1929/agriambi.v19n4p309-316

Baia Z, Casparia T, Gonzaleza MR, Batjesa NH, Mäderb P, Bünemannb EK, De Goedec R, Brussaardc L, Xud M, Ferreirae CSS, Reintamf E, Fang H, Miheličh R, Glavanh M, Tóth Z (2018) Effects of agricultural management practices on soil quality: A review of long-term experiments for Europe and China. Ecosystems and Environment 265(1):1-7. DOI:

https://doi.org/10.1016/j.agee.2018.05.028

Blum J, Giarola NFB, Silva ÁP, Filho OG, Silva SGC, Eberhardt DN, Araújo SR (2014) Assessment of soil physical attributes at sowing row and inter-row under notill system. Revista Ciência Agronômica 45(5) (Especial): 888-895. DOI: http://dx.doi.org/10.1590/S180666902014000500004
Bünemann EK, Bongiorno G, Bai ZG, De Goede R, Mäder P, Sukkel W, Brussaard L (2018) Soil quality - a review. Soil Biology Biochemistry 120(1):105-125. DOI: https://doi.org/10.1016/j.soilbio.2018.01.030

Castela Junior MA, Oliveira TC, Figueiredo ZN, Samogim EM, Caldeira DAS (2014) Influência da velocidade da semeadora na semeadura direta da soja. Enciclopédia Biosfera 10(19):1199-1207.

Castilho KB, Cortez JW, Olszevski N, Salviano AM, Trindade MH (2017) Análise multivariada da qualidade química de um Latossolo sob sistemas de manejo do solo. Agrarian 10(36):162-169.

Cortez JW, Mauad M, Souza LCF, Rufino MV, Souza PHN (2017) Agronomical attributes of soybeans and soil resistance to penetration in no-tillage and chiseled surfaces. Revista de Engenharia Agrícola 37(1):98-105. DOI: http://dx.doi.org/10.1590/1809-4430eng.agric.v37n1p98-105/2017

Donagema GK, Campos DVB, Calderano SB, Teixeira WG, Viana JH (2011) Manual de métodos de análise de solos. Rio de Janeiro, Embrapa Solos, 230p.

Embrapa - Empresa Brasileira de Pesquisa Agropecuária (2013) Sistema Brasileiro de Classificação de Solos. Brasília, Embrapa Solos, 353p.

Freitas L, Oliveira IA, Silva LS, Frare JCV, Filla VA, Gomes RP (2017) Indicadores da qualidade química e física do solo sob diferentes sistemas de manejo. Revista Unimar Ciências 26(1):1-12.

Girardello VC, Amado TJC, Santi AL, Lanzanova ME, Tasca A (2017) Resistência do solo à penetração e desenvolvimento radicular da soja sob sistema plantio direto com tráfego controlado de máquinas agrícolas. Revista Scientia Agraria 18(2):86-96. DOI: http://dx.doi.org/10.5380/rsa.v18i2.50693

Frederico-Gomes F, Garcia CH (2002) Estatística aplicada a experimentos agronômicos e florestai: exposição com exemplos e orientações para uso de aplicativos. Piracicaba, Fealq, 309p.

Luciano RV, Albuquerque JA, Mafra AL, Costa JG, Grah $\mathrm{J}$ (2014) Water storage variability in a vineyard soil in the southern highlands of Santa Catarina state. Revista Brasileira de Ciência do Solo 38(1):82-93. DOI: http://dx.doi.org/10.1590/S0100-06832014000100008

Mahmoudi A, Jalali M, Valizadeh IS (2015) The effects of forward speed and depth of conservation tillage on soil bulk density. Journal of Agricultural Machinery 5(1):380-368.

Moraes MT, Debiasi H, Carlesso R, Franchini JC, Silva VR (2014) Critical limits of soil penetration resistance in a rhodic eutrudox. Revista Brasileira de Ciência de Solo 38(1):288-298. DOI: http://dx.doi.org/10.1590/S010006832014000100029

Novak E, Carvalho LA, Santos, LL, Hernando ID, Panachuki E (2017) Densidade do solo e densidade relativa de um latossolo vermelho submetido a diferentes usos. Agrotrópica 29(1):31-38. DOI:

http://dx.doi.org/10.21757/0103-3816.2017v29n1p5-12 
Oliveira DMS, Lima RP, Verburg EEJ (2015) Qualidade

física do solo sob diferentes sistemas de manejo e aplicação de dejeto líquido suíno. Revista Brasileira de Engenharia Agrícola e Ambiental 19(3):280-285. DOI:

http://dx.doi.org/10.1590/1807-1929/agriambi.v19n3p280-285

Reynaldo EF, Machado TM, Taubinger L, Tabelas D, Scwartz SR (2016a) Avaliação de semeadora adubadora pneumática analisando espaçamentos entre plantas e produtividade. Enciclopédia Biosfera 13(23):155-162. DOI: http://dx.doi.org/10.18677/Enciclopedia_Biosfera_2016_014

Reynaldo EF, Machado TM, Taubinger L, Tabelas D, Scwartz SR (2016b) Influência da velocidade de deslocamento na distribuição de sementes e produtividade de soja. Engenharia na Agricultura 24(1):63-67.

Rodrigues FS, Cortez JW, Souza CMA, Viero RM, Souza PHN, Pusch M (2017) Variabilidade espacial da resistência do solo à penetração em sistema plantio direto. Revista Plantio Direto \& Tecnologia Agrícola 160:08-14.

Sales RP, Portugal AF, Moreira JAA, Kondo MK, Pegoraro RF (2016) Qualidade física de um Latossolo sob plantio direto e preparo convencional no semiárido. Revista Ciência Agronômica 47(3):429-438. DOI: http://dx.doi.org/10.5935/1806-6690.20160052
Santana JS, Lima EF, Komatsu RS, Silva WA, Ribeiro MID (2018) Caracterização física e química de solo em sistemas de manejo plantio direto e convencional. Enciclopédia biosfera 15(27):22-42.

Santos TD, Meert L, Borghi WA, Silva OS, Figueiredo AST (2017) Desenvolvimento inicial de plantas de soja e qualidade de semeadura em função da velocidade de deslocamento da semeadora e textura de solo. Brazilian Journal of Applied Technology for Agricultural Science, 10(2):97-103. DOI: http://dx.doi.org/10.5935/PAeT.V10.N2.10

Silva NF, Cunha FN, Cunha RC, Cabral Filho FR, Teixeira MB, Carvalho JJ (2014) características físicohídricas de um Latossolo sob diferentes sistemas de manejo. Revista Brasileira de Agricultura Irrigada 8(5):375-390.

Stolf R (1991) Teoria e teste experimental de fórmulas de transformação dos dados de penetrômetro de impacto em resistência do solo. Revista Brasileira de Ciência de Solo 15(1):229-235.

Stolf R, Murakami JH, Maniero MA, Silva LCF, Soares MR (2012) Incorporação de régua para medida de profundidade no projeto do penetrômetro de impacto Stolf. Revista Brasileira de Ciência de Solo 5(1):1476-1482. 